\title{
Hepatolithiasis: clinical series, review and current management strategy
}

Osman Nuri Dilek ${ }^{1}$ (D), Ahmet Atasever ${ }^{1}$ (D), Nihan Acar ${ }^{1}$ (D), Şebnem Karasu²(D), Emine Özlem Gür ${ }^{1}$ (D), Oğuzhan Özşay ${ }^{1}$ (D), Hakan Çamyar ${ }^{3}$ (D), Fatma Hüsniye Dilek ${ }^{4}$ (D)

\footnotetext{
${ }^{1}$ Department of Surgery, İmir Katip Çelebi University School of Medicine, İmir, Turkey

2 Department of Radiology, İzmir Katip Çelebi University School of Medicine, İmir, Turkey

${ }^{3}$ Department of Gastroenterology, İzmir Katip Çelebi University, Atatürk Training and Research Hospital, İzmir, Turkey

${ }^{4}$ Department of Pathology, İzmir Katip Çelebi University School of Medicine, İzmir, Turkey
}

\begin{abstract}
Objective: Hepatolithiasis ( $\mathrm{HL}$ ) continues to be a problem due to its local and systemic complications, insufficiency in treatment modalities and high risk of recurrence. There are various surgical options available, ranging from endoscopic interventions to a small segment resection and ultimately to transplantation. In this article, patients with the diagnosis of $\mathrm{HL}$ and our treatment strategies were evaluated in the light of literature.

Material and Methods: The patients diagnosed with HL in our clinic between 2014-2019 were evaluated retrospectively by examining the patient files. Demographic characteristics of the patients, causes of the disease, complications and treatment options were evaluated.

Results: 17 patients were included into the study. Mean age of the patients was 64.3 years (range 32-89 years). Seven patients had previous cholecystectomies. Stenosis was found to be developed in hepaticojejunostomy (HJ) site in three patients (two had HJ due to bile duct injury and one had HJ following the Whipple procedure), and in hepaticoduodenostomy site in one patient who had the history of biliary tract injury during cholecystectomy. Two patients with HL without previous cholecystectomies had no gallbladder stones. Nine patients underwent surgery. Left hepatectomy was performed in two patients and lateral sector resection was performed in 2 patients. Two patients with anastomotic stenosis underwent $\mathrm{HJ}$ revision and two patients with anastomotic stenosis and one patient with stent ingrowth underwent bifurcation resection and neo-hepaticojejunostomy. Eight patients were followedup nonoperatively with medical and endoscopic approaches.
\end{abstract}

Conclusion: Hepatolithiasis is a serious condition that needs to be treated with a multimodal approach. Stenting and anastomotic stenosis facilitate the development of hepatolithiasis and increase the risk of its occurrence. In particular, by performing functional hepaticojejunostomy, the development of this complication will be decreased.

Keywords: Anastomosis, bile duct stricture, etiology, hepatolithiasis, treatment

Cite this article as: Dilek ON, Atasever A, Acar N, Karasu S, Gür EÖ, Özşay O, et al. Hepatolithiasis: clinical series, review and current management strategy. Turk J Surg 2020; 36 (4) 382-392.

Corresponding Author

Osman Nuri Dilek

E-mail: osmannuridilek@gmail.com

Received: 10.06 .2020

Accepted: 12.08 .2020

Available Online Date: 29.12 .2020

(- Copyright 2020 by Turkish Surgical Society Available online at www.turkjsurg.com

DOI: $10.47717 /$ turkjsurg.2020.455

\section{INTRODUCTION}

The term primary hepatolithiasis $(\mathrm{HL})$ (also known as oriental cholangiohepatitis) refers to stones in the intrahepatic bile duct prior to the bifurcation of the common bile duct. It has been known since the 16th and 17th centuries. The incidence of HL varies by country. The rate is around $2-25 \%$ in far east countries. In Taiwan, $\mathrm{HL}$ accounts for about $25 \%$ of the patients with gallstones. This rate is $15 \%$ in Hong Kong and $4 \%$ in Japan. The incidence in Western countries is approximately 1\% (1-3). In Europe and America, the incidence of $\mathrm{HL}$ increases due to migrations. The global incidence has increased from $0.32 / 100.000$ to $0.85 / 100.000$ in the last three decades $(3,4)$. Interestingly, in eastern countries where westernized diet has become more common, the incidence has been decreasing.

Although the exact etiology of the disease is unknown, cholestasis, biliary strictures, infection, anatomical anomalies and disorders in bile metabolism are considered as the most important predisposing factors (4-6). In addition to these, genetic mutations and ethnic differences play a role in etiology. Lipopolysaccharides have been shown to induce endogenous $\beta$-glucuronidase and c-myc release from hepatocyte and intrahepatic biliary epithelium and contribute to the formation of pigment stones. In East Asian countries, ascaris infestations especially Clonorchis sinensis as a result of raw fish consumption are responsible for $30 \%$ of the cases $(7,8)$. 
Japanese researchers have described patients with $\mathrm{HL}$ clinically in four different grades. According to this, patients with no clinical symptoms are classified as Grade 1, those with abdominal pain as Grade 2, patients with transient jaundice and cholangitis as Grade 3 , and those with recurrent jaundice, sepsis and intrahepatic cholangiocarcinoma (ICCA) as Grade 4 (2). On the other hand, Liu et al. (9) have classified HL as follows; the primary type without a past surgical history as type 1, inflammatory type with previous surgery and episodes of cholangitis as type 2, complicated type that forms a mass in the liver as type 3 and terminal type with severe cirrhosis and portal hypertension as type 4. The Dong classification is based on the treatment approach. Type 1 is localized disease and type 2 contains multiple $\mathrm{HL}$ divided into three different subgroups. The presence of extra-liver stones in this classification is defined as type E with three subgroups (10-12). Suzuki et al. (13) have classified $\mathrm{HL}$ as Grade 1, 2 and 3 according to minor (over 65 years of age, jaundice $>1$ week) and major (cirrhosis, HL-ICCA) factors contributing to the severity of the disease.

The first choice in the diagnosis of HL is ultrasound (US) and computed tomography (CT). Ultrasound has the advantages such as being non-invasive, practical and accessible. It is also very useful in determining the location, size, echogenicity, and shadowing characteristics of the stones. Computed tomography is performed in the identification of dilated ducts, stricture regions, masses and calcified lesions (Figure 1). With these two methods, $66-87 \%$ of the cases can be diagnosed $(7,14)$. More detailed information on stenosis may be available with intraoperative US, endoscopic US (EUS) and intraductal US (IDUS) $(15,16)$. A comet tail sign on the endoscopy shows the location of the stones and stenosis (14). Magnetic resonance imaging (MRI) and magnetic resonance cholangiopancreatography (MRCP) are also beneficial in the differential diagnosis of intraductal lesions, in the detection and localization of the stones (Figure 2). PET-CT can be utilized for the diagnosis of HL-ICCA-induced mass lesions and distant metastases with a ring-shaped image. The strictures in the bile ducts can be best detected by cholangiography and cholangioscopy. As long as there is no risk of atrophy or HL-ICCA in the liver, US and MRI are recommended for follow-up. Most of the cases with $\mathrm{HL}$ (85\%) are diagnosed with preoperative imaging methods while in some cases (15\%), they are diagnosed during surgery and endoscopic procedures (14-16).
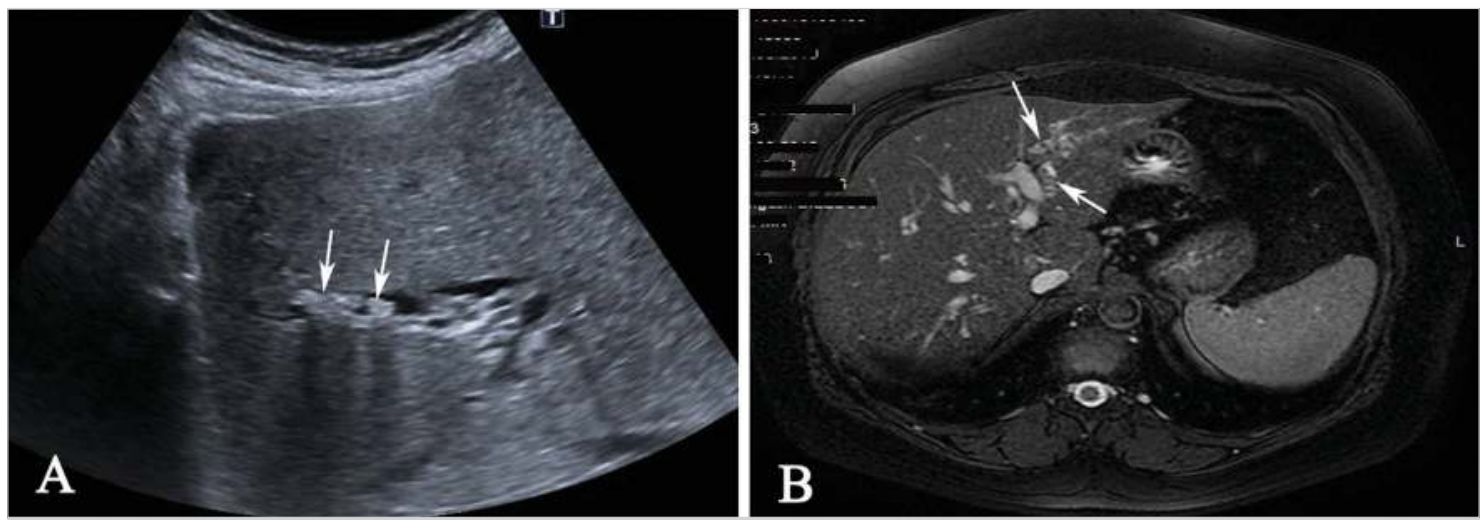

Figure 1. The ultrasonography of the liver shows (A) the stones in the left hepatic bile ducts and their reflections (acustic shadow). Axial tomography section (B) of the same patient shows multiple stones in the left lateral sector.
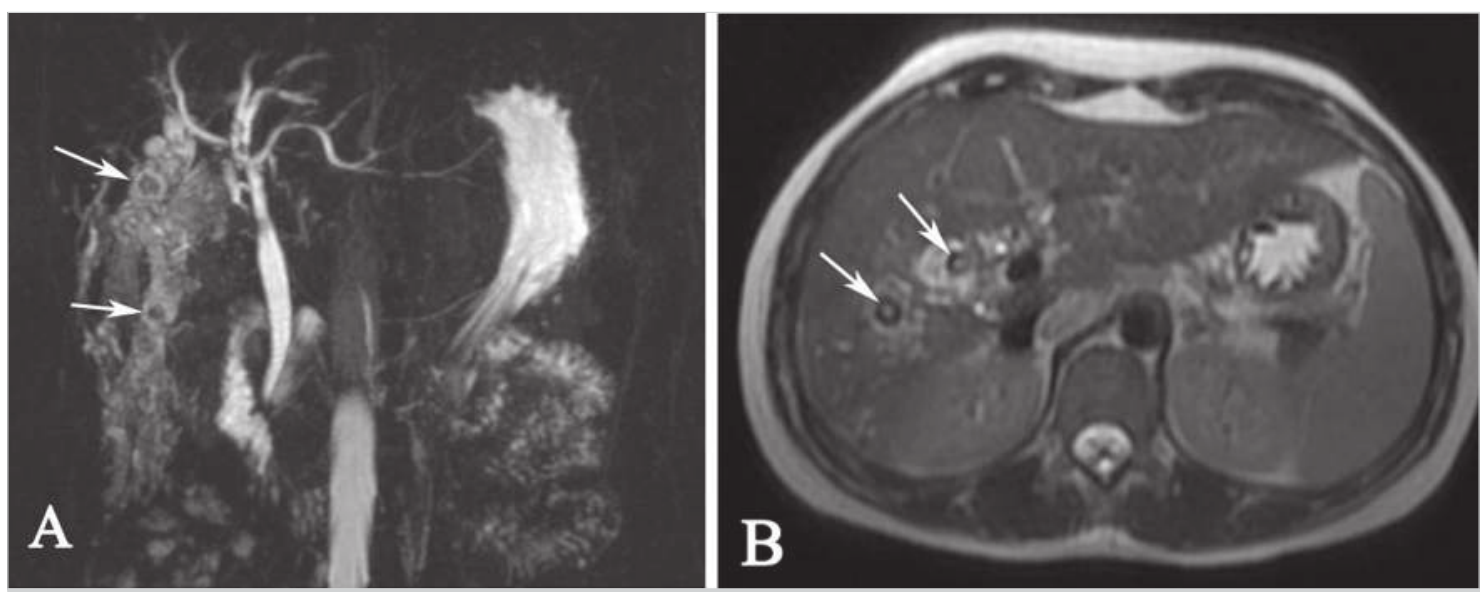

Figure 2. The axial (A) and coronal (B) sections of MRCP figures show multiple stones in the right bile ducts. 
Interventional instruments (balloon, steerable catheters, forceps, lithotripsy instruments), endoscopic methods such as endoscopic retrograde cholangiopancreatography (ERCP) and percutan transhepatic cholangiography (PTC), and surgical procedures are used in the treatment. There is not adequate data on medical treatment, it has limited efficacy especially in primary patients $(10,11)$. In cases of $\mathrm{HL}$ caused by parasitic infections, antihelmintic drugs are also added to the treatment $(2,8)$. Endoscopic methods are used primarily in treatment-resistant cases. In cases where medical treatments and endoscopic interventions are insufficient, there are surgical options ranging from operative endoscopy, anastomosis revisions, a small segment resection to liver transplantation.

Here, our approach to HL cases in the last four years was examined in the light of the literature.

\section{MATERIAL and METHODS}

The retrospective study protocol was approved by the institutional Ethics Committee (Number: 260, Date: 30.05.2019). A written informed consent was obtained from each patient for both treatment modalities and publication. The study was conducted in accordance with the principles of the Declaration of Helsinki.

\section{Patients}

In this study, patients who were diagnosed with HL between 2014 and 2019 in our department of general surgery were included. Medical records of the patients were retrospectively evaluated, and the patients with unavailable follow-up data were excluded. The patients with choledochal stones were also not included into the study. Demographics, comorbidities, etiology of hepatolithiasis, presenting complaint, laboratory tests, imaging results, grade of the disease, treatment methods, surgical procedures, pathology results, complications and morbidity/ mortality were assessed.

\section{Diagnosis and Management of Hepatolithiasis}

Patients were either admitted to our clinic or referred from gastroenterology clinic. Ultrasound, CT and EUS were the initial imaging methods. Diagnosis of HL was confirmed with MRCP, ERCP and/ or PTC. Brush biopsy sampling was performed in required cases.

In terms of conservative treatment, parenteral antibiotics were administered and endoscopic interventions were performed in the presence of cholangitis. Ursodeoxycholic acid (UDCA) was prescribed to the patients who were candidates for nonoperative follow-up.

Failed endoscopic interventions, recurrent episodes of cholangitis despite endoscopic interventions and presence of the suspicion of malignancy constituted the indications for surgery. Hepatectomy and hepaticojejunostomy $(\mathrm{HJ})$ were the performed surgical procedures. All HJs were carried out with Rouxen-Y technique. Patients were followed up with four months period of outpatient visits during the first year and then annually.

\section{Statistical Analysis}

Descriptive statistics (mean, standard deviation, $\mathrm{n}$ and percentile) for discrete and continuous variables were given. The assumption of normality was tested via the Shapiro-Wilk test. Descriptive analysis was conducted via SPPS 20 (IBM Corp. Released 2011. IBM SPSS Statistics for Windows, Version 20.0. Armonk, NY: IBM Corp.).

\section{RESULTS}

Seventeen patients with $\mathrm{HL}$ were included into the study. Ten patients were females, and mean was 64.3 years (range: 32-89 years). The most common complaints were abdominal pain, intermittent jaundice and fever. Seven patients had previously undergone cholecystectomy.

Demographic data of the patients are shown in Table 1.

Majority of the cases had Grade III HL according to Japanese classification (n: 12, 70.5\%). Stenosis was detected in four patients. It was found to be developed in $\mathrm{HJ}$ site in three patients (two had $\mathrm{HJ}$ due to bile duct injury and one had $\mathrm{HJ}$ following the Whipple procedure), and in hepaticoduodenostomy site in one patient who had the history of biliary tract injury during cholecystectomy. Two patients with $\mathrm{HL}$ and without previous cholecystectomies had no gallbladder stones. US, EUS, MRCP, CT, PTC and recurrent ERCP methods were used for diagnostic and therapeutic purposes.

Surgical treatment was required in nine patients. Left hepatectomy was performed in two patients and lateral sector resection was performed in two patients (Figure 3). Among the four patients with anastomotic stenosis, two underwent $\mathrm{HJ}$ revision and the remaining two underwent bifurcation resection and neo-hepaticojejunostomy (collector type portoenterostomy). Collector type portoenterostomy was also performed in one patient with metallic stent ingrowth. One patient underwent laparoscopic cholecystectomy and was followed-up. Most common postoperative complication was surgical site infection which occurred in four patients, and bile fistula accompanied one of them. Postoperative mortality did not occur in any patient.

Eight patients were followed-up nonoperatively with medical and endoscopic approaches. Three of these patients underwent stone extraction and stenting with ERCP and were followed-up with repeated ERCPs. One patient without any further symptoms and clinical problems, one patient who had been receiving medical treatment due to thymoma and one patient who did not consent to operation were followed up conservatively. An 89-year-old patient died due to cholangiohepatitis and sepsis. A patient who was scheduled for a left hepatectomy awaited the remission from the current systemic disease (Pemphigus vulgaris). Recurrent cholangitis was the most common complication among the patients who underwent nonoperative management (n: 5). 
Table 1. Demographic data of the patients with Hepatolithiasis

\begin{tabular}{|c|c|c|c|c|c|c|c|}
\hline & Age & Sex & Diagnosis/Grade $(*)$ & Etiology/Comorbities & Intervention/Treatment & Complication & Follow up \\
\hline 1. & 82 & M & $\begin{array}{l}\text { R\&L HL (2015) } \\
\text { (Grade III) }\end{array}$ & $\begin{array}{c}\text { Vagotomy + Billroth } 2 \\
\text { (1995) } \\
\text { Cholecystectomy + } \\
\text { BD Trauma (2013) }\end{array}$ & $\begin{array}{c}\text { ERCP fail } \\
\text { Neo-HJ + Permanent access } \\
(2016)\left({ }^{* *}\right)\end{array}$ & $\begin{array}{l}\text { Bile fistula } \\
\text { Cholangitis } \\
\text { SSI }\end{array}$ & Follow \\
\hline 2. & 66 & $\mathrm{~F}$ & $\begin{array}{l}\text { L HL (2013) } \\
\text { (Grade III) }\end{array}$ & $C L+C D L$ & $\begin{array}{l}\text { ERCP fail, PTC + Stenting } \\
\text { Cholecystectomy + } \\
\text { Left hepatectomy (2015) }\end{array}$ & SSI & Health \\
\hline 3. & 32 & M & $\begin{array}{l}\text { L HL (2013) } \\
\text { (Grade III) }\end{array}$ & $\begin{array}{l}\mathrm{CL}+\text { Left portal vein } \\
\text { thrombosis (?) }\end{array}$ & $\begin{array}{c}\text { Cholecystectomy + } \\
\text { Left hepatectomy (2015) }\end{array}$ & - & Health \\
\hline 4. & 89 & M & $\begin{array}{l}\text { L HL (2011) } \\
\text { (Grade IV) }\end{array}$ & $\begin{array}{c}\text { Vagotomy }+ \text { Billroth } 2 \\
(1998) \\
C L\end{array}$ & $\begin{array}{l}\text { ERCP fail, PTC + Stenting + } \\
\text { UDCA }(2011,2012,2014)\end{array}$ & $\begin{array}{c}\text { Cholangitis + Sepsis } \\
+ \text { MODS }\end{array}$ & $\begin{array}{l}\text { Excitus } \\
(2014)\end{array}$ \\
\hline 5. & 41 & M & $\begin{array}{c}\text { Segment } 6 \text { (2015) } \\
\text { (Grade II) }\end{array}$ & $\begin{array}{c}\text { Timoma }+ \text { Lung metastasis } \\
\text { (2011) } \\
C L+C D L\end{array}$ & Follow & Cholangitis? & Follow \\
\hline 6. & 83 & $\mathrm{~F}$ & $\begin{array}{l}\text { R\&L HL (2014) } \\
\text { (Grade III) }\end{array}$ & $\begin{array}{l}\text { Cholecystectomy (2008) } \\
\text { CDL }\end{array}$ & $\begin{array}{c}\text { ERCP + Stenting + Baloon } \\
(2017)\end{array}$ & Cholangitis & Follow \\
\hline 7. & 75 & M & $\begin{array}{c}\text { Segment 2-3 (2015) } \\
\text { (Grade II) }\end{array}$ & $\begin{array}{l}\text { Pneumonia (2015) } \\
\text { CL }\end{array}$ & Cholecystectomy (2015) & Left liver atrophy & Follow \\
\hline 8. & 76 & $\mathrm{~F}$ & $\begin{array}{l}\text { L HL (2011) } \\
\text { (Grade III) }\end{array}$ & Cholecystectomy (2001) & $\begin{array}{c}\text { ERCP (9) + EST + Baloon + } \\
\text { Stenting (2014) } \\
\text { Operation (Left hepatectomy) } \\
\text { refused }\end{array}$ & Cholangitis & Follow \\
\hline 9. & 43 & $\mathrm{~F}$ & $\begin{array}{l}\text { R\&L HL (2015) } \\
\text { (Grade III) }\end{array}$ & $\begin{array}{l}\text { Whipple procedure (2004) } \\
\qquad \text { HJ stenosis (2015) }\end{array}$ & HJ revision (2017) & SSI & Health \\
\hline 10. & 53 & M & $\begin{array}{l}\text { R HL (2015) } \\
\text { (Grade III) }\end{array}$ & - & $\begin{array}{c}\text { ERCP (3) + EST + Baloon + } \\
\text { Stenting (2016) + UDCA }\end{array}$ & Cholangitis & Follow \\
\hline 11. & 59 & $\mathrm{~F}$ & $\begin{array}{l}\text { L HL (2015) } \\
\text { (Grade III) }\end{array}$ & CL (2009) & $\begin{array}{c}\text { ERCP }(2)+E S T+\text { Baloon } \\
\text { Cholecystectomy + Left sector } \\
\text { resection (2016) }\end{array}$ & SSI & Health \\
\hline 12. & 82 & $\mathrm{~F}$ & $\begin{array}{l}\text { R\&L HL (2013) } \\
\text { (Grade II) }\end{array}$ & Cholecystectomy (2010) & - & Left liver atrophy & Follow \\
\hline 13. & 34 & $\mathrm{~F}$ & $\begin{array}{l}\text { Segment 6-7 (2016) } \\
\text { (Grade I) }\end{array}$ & Cholecystectomy (2016) & $\begin{array}{c}\mathrm{ERCP}(2)+\mathrm{EST}+\text { Baloon } \\
+\mathrm{UDCA}\end{array}$ & - & Follow \\
\hline 14. & 74 & $\mathrm{~F}$ & $\begin{array}{l}\text { R\&L HL (2014) } \\
\text { (Grade III) }\end{array}$ & $\begin{array}{l}\text { Cholecystectomy + BD } \\
\text { Trauma + HJ (2007) } \\
\text { HJ stenosis + PTC + } \\
\text { Stent ingrowth }\end{array}$ & $\begin{array}{c}\text { ERCP + Stenting followed by } \\
\text { PTC + Stenting } \\
\text { Neo-HJ (2017) }\end{array}$ & - & Health \\
\hline 15. & 76 & M & $\begin{array}{l}\text { L HL (2015) } \\
\text { (Grade III) }\end{array}$ & $\begin{array}{l}\text { Bullous pemphigoid + } \\
\text { Pemphigus vulgaris } \\
\text { (Streoid treatment) }\end{array}$ & $\begin{array}{c}\text { ERCP + EST + Baloon (2017) } \\
\text { Operation (Left hepatectomy) } \\
\text { suggested? }\end{array}$ & - & Follow \\
\hline 16. & 61 & $\mathrm{~F}$ & $\begin{array}{l}\text { R\&L HL (2009) } \\
\text { (Grade III) }\end{array}$ & $\begin{array}{c}\text { Cholecystectomy + BD } \\
\text { Trauma (2008) } \\
\text { HJ Stenosis (2009) }\end{array}$ & $\begin{array}{c}\text { HJ revision } \\
2009 \text { and } 2010+\text { UDCA }\end{array}$ & $\begin{array}{c}\text { Fistula } \\
\text { Cholangitis }\end{array}$ & Follow \\
\hline 17. & 64 & $\mathrm{~F}$ & $\begin{array}{l}\text { L HL (2017) } \\
\text { (Grade III) }\end{array}$ & $\begin{array}{c}\text { Cholecystectomy (2004) + } \\
\text { HL (2019) }\end{array}$ & Lateral sector resection & - & Follow \\
\hline \multicolumn{8}{|c|}{$\begin{array}{l}\text { *: Classification (Japan), } \\
\text { **: Hepatico-cutaneous jejunostomy. } \\
\text { BD: Main bile duct, CL: Cholelithiasis, CDL: Choledocholithiasis, ERCP: Endoscopic retrograde cholangiopancreatography, EST: Endoscopic sphincterotomy, HJ: Hepat } \\
\text { cojejunostomy, HL: Hepatolithiasis, PTC: Percutan transhepatic cholangiography, R/L: Right/Left, SSI: Surgical site infection, UDCA: Ursodeoxycholic acid. }\end{array}$} \\
\hline
\end{tabular}



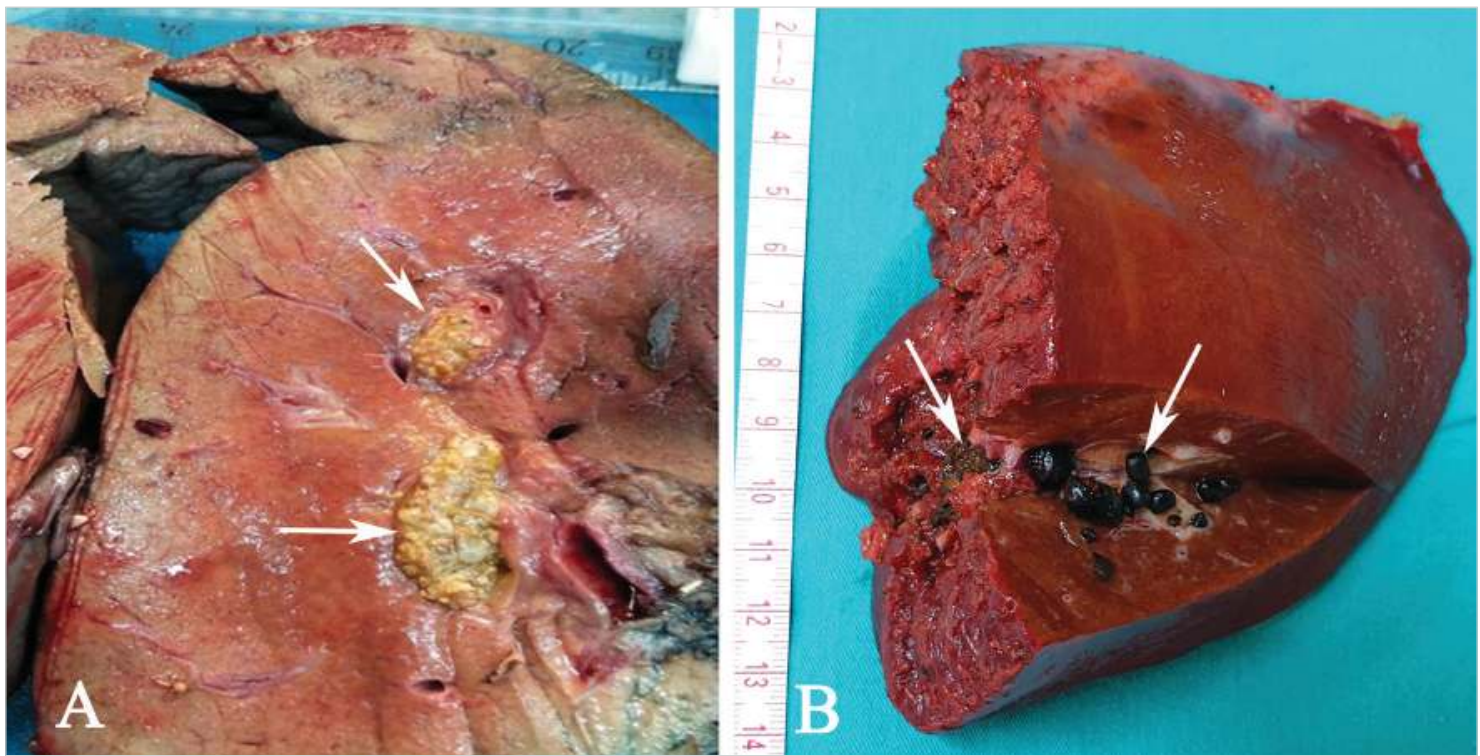

Figure 3. Left hepatectomy specimen (A) shows yellow-green multiple stones in the left hepatic main bile ducts and lateral sector specimen (B) shows multiple black stones in the bile ducts of segment 3.

Mean duration of follow-up was 43 months (range: 24-70) None of the patients who underwent surgical treatment developed any late postoperative complication or recurrence.

\section{DISCUSSION}

The main principle in the treatment of $\mathrm{HL}$ is the removal of stones, correction of related strictures and prevention of recurrent cholangitis. Stenosis of the biliary tract is the main cause of stone formation, recurrence, and failure of treatment $(8,17,18)$. In patients with untreated $\mathrm{HL}$, lethal complications, which may vary from cholestasis and cholangitis to sepsis, cirrhosis, and ICCA may develop. Depending on the duration of follow-up, it is reported that $3.7 \%-14.1 \%$ of HL cases develop biliary cirrhosis and 3.3-21.2\% develop HL-related intrahepatic cholangiocellular carcinoma (HL-ICCA) $(4,13,19-21)$.

As a result of recurrent cholestasis and cholangitis episodes, biliary cirrhosis develops due to stenosis that occurs in the ducts as a result of fibrosis. Chen et al. (22) have found that a precancerous lesion of biliary tract, which is called intraductal papillary neoplasia, is encountered in $30 \%$ of HL cases $(23,24)$. Presence of $\mathrm{HL}$ is considered as a precancerous lesion for ICCA (4). Biliary intraepithelial neoplasia, a precancerous lesion in the areas close to the lesion, is also frequently detected in the specimens of patients undergoing resection for HL-ICCA. It has been shown that c-erbB2, epidermal growth factor (EGFR), COX-2 and nuclear factor-KB (NF-KB) which are markers of prolonged inflammation are higher in cases developing HL-ICCA $(23,25)$. p16 and DPC4/ Smad4 genes which are tumor suppressor genes are frequently inactivated in patients with HL-ICCA (26). It should be kept in mind that the risk of ICCA is higher in patients with biliary stricture, liver atrophy, high levels of CA 19-9, in cases of HL especially located on the left side, in the presence of microabscess and in patients with choledochoenterostomies $(4,13,21,27)$. The risk of tumor increases in bilateral HL cases $(28,29)$.

There is very little clinical data on the medical treatment of $\mathrm{HL}$. There is not yet a suitable drug for $\mathrm{HL}$ which is rich in pigment in the majority. However, there are limited clinical studies on the effect of UDCA and kenodeoxycholic acid (CDCA) for cholesterol stones which present in $15 \%$ of $\mathrm{HL}$ cases (30-34). In their series of 3 cases of Caroli syndrome, Ros et al. (32) achieved partial cure in 9 patients and full recovery in 3 patients with extracorporeal shock-wave lithotripsy (ESWL) and UDCA therapy. There are many cases reported to benefit from ESWL+UDCA, and with only UDCA in the series of 53 patients by Guma et al. (35). Regarding this subject, in their evidence-based clinical practice study from Japan, Tazuma et al. (30) have pointed out that medical treatment cannot be recommended (Strength of recommendation degree is $2-\% 100)$ (31). However, algorithms related to UDCA and CDCA use have been determined especially in cholesterol-rich stones and in some special clinical situations. According$\mathrm{ly}$, it has been reported that the stones disappear in $25 \%$ of $\mathrm{HL}$ cases with Caroli syndrome with 6-12 months of UDCA treatment, and it diminishes $75 \%$ of the stones. In addition, UDCA administration has been reported to prevent relapse in $\mathrm{HL}$ patients with MDR3 deficiency (a genetic disorder causing intrahepatic cholestasis). UDCA has also been reported to be used in $\mathrm{HL}$ cases with cholesterol oversaturation and negative X-rays (30, 31). There are studies reporting that the use of UDCA in patients with $\mathrm{HL}$ prevents the development of HL-ICCA $(35,36)$. De Vries and Beuers (33) stated that UDCA is the standard treatment for cholestasis due to primary biliary cholangitis (PBC) and primary 


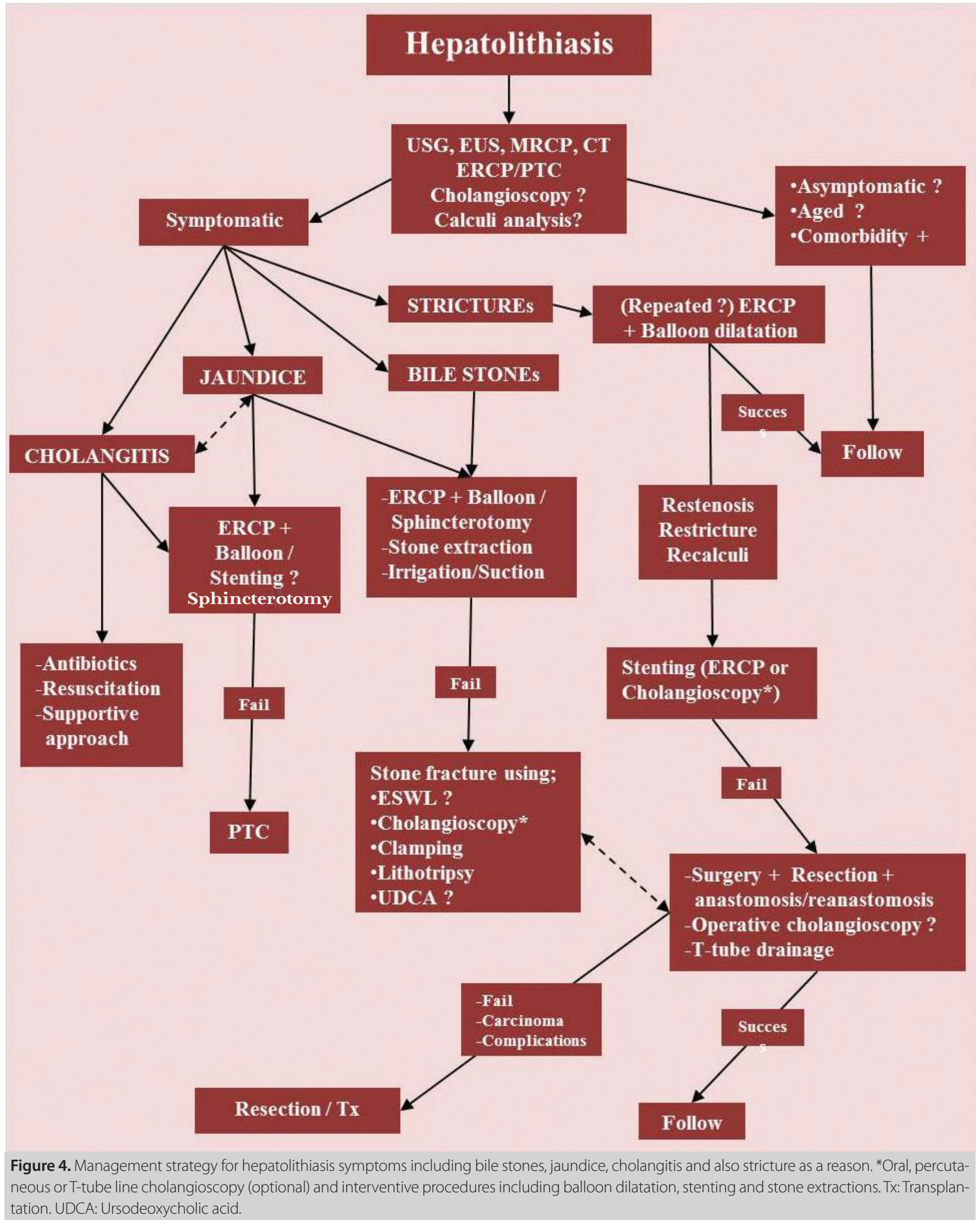


sclerosing cholangitis (PSC). UDCA was used in 4 patients (1 revised $\mathrm{HJ}$ and 3 medical follow-ups) in our series.

Until the 1970s, HL treatment consisted of cholecystectomy, extraction of stones in the main bile ducts and T-tube application. A significant improvement has been achieved in treatment when Nakamura used choledochoscopy to remove residual biliary calculi (37). Surgical treatment was the first choice until 2000, but with the increase of the use of choledochoscope and ERCP, the need for surgical treatment started to decrease. Irrigation of the biliary tract, removal of the stones by endoscopic instruments and steerable catheters and percutaneous lithotripsy are used for treatment. In the last decade, surgical treatment is required in $33-77 \%$ of $\mathrm{HL}$ cases depending on the centers and technological resources $(7,28,37)$. Surgical procedures were required in half of the cases in our series. Lorio et al., in 2020, offered endoscopic or combined interventional radiology/endoscopy management as a first line treatment in $\mathrm{HL}$ since these interventions had relatively lower complication rates (38). Surgery was proposed as a secondary choice in this study when minimally invasive interventions failed. In our study, all cases initially underwent ERCP and PTC when possible.

Strictures are tried to be treated primarily by endoscopic methods (Figure 4). For this purpose, first, balloon dilatation, bougie dilatation, and needle-knife electrocautery can be used. Extraction of the stones behind the stenosis by using a basket can expand the area of the stenosis. It may also be necessary to place a stent in the stubborn stenosis areas of the main bile duct (39). In the four cases from our series (25\%), HL developed as a result of the stenosis after a bile duct operation. In all of these patients, recurrent ERCP or PTC procedures were not sufficient due to recurrent stones and cholangitis so, a corrective surgery was performed.

Nowadays, removal of the stones by sphincterotomy, choledochoscopy and basket with ERCP and by lithotripsy (pneumatic, hyperacoustic, electrohydrolic or laser) are the most commonly used methods (Figure 4). Although there are very few studies, it has been reported that stones may disintegrate with ESWL in $60-90 \%$ of the cases that have no bile duct stenosis (31). The removal of the disintegrated stones by saline irrigation facilitates the procedure. Choledochoscopy can be performed from the normal gastrointestinal tract (per-oral) and as well as from the $T$ tube tract. For the cholangioscopy performed from the $T$ tube tract, the $T$ tube should be kept for at least 4 weeks in normal patients and for 12 weeks in cachectic or diabetic patients (14). Endoscopic approaches may be preferred due to the risk of insufficient liver residue after hepatectomy or the fact that $\mathrm{HL}$ is bilateral. ERCP should be preferred in cases with stones in the main bile duct (Figure 4). In their series with 42 permanent access (hepatico-cutaneous jejunostomy) cases, Kassem et al. (40) have reported that they successfully treated remnant stones and recurrent stones (40). Choi et al. (1) have reported that the addition of permanent access (hepatico-cutaneous jejunostomy) to the treatment, especially in patients with previous HJs, would be very useful in the treatment of stenoses that will occur in later stages and the removal of Stones. They stated that repeating the choledochoscopy procedure with an interval of 5-7 days and cleaning off the mud and small particles with continuous saline irrigation is much more effective. Recurrent ERCP procedures were performed for diagnosis and treatment in 7 of our patients. The most common complaints after cholangioscopy and stone extraction are pain and fever, and antibiotics and transamines are recommended in the treatment because of the risk of cholangitis and bleeding $(1,8,14)$. In Japanese surveys, $22 \%$ of the patients (range from 5 to 54) have been reported to develop recurrence, cholangitis, abscess, and ultimately HL-ICCA cancer after cholangioscopy (31). In a series of 396 patients followed by an average of 308 months by Suzuki et al., 118 patients died and the most common cause of death was HL-ICCA in 25 (21.2\%) patients. This was followed by deaths due to liver cirrhosis (11 patients, 9.3\%), lung diseases (10 patients, 8.5\%) and cholangitis + liver abscesses (9 patients, 7.6\%) (36).

On the other hand, it is known that reflux caused by laxation in the Oddi sphincter after sphincterotomy with ERCP increases the risk of development of cholangitis and $\mathrm{HL}$. For this reason, it is recommended to perform balloon dilatation first and then sphincterotomy in cases when necessary (20). In cases where the biliary tract is enlarged, percutaneous transhepatic biliary drainage (PTBD) which was first described by Mondet in 1962, may be preferred in opening of the strictures and extraction of the stones $(14,40,41)$. Shin et al. (42) stated that there were some disadvantages of sphincterotomy with ERCP and developed the PTBD method (balloon sphincterotomy and flushing technique) and published a large series. In their large series with 916 cases, they reported that they entered the canal with the PTBD technique, they performed sphincterotomy with a balloon and completely cleaned the stones by using the flushing technique in 92.3\% of the cases.

In the treatment of primary $\mathrm{HL}$, even though there are many technological procedures, there is still a condition of being insufficient. Despite all technological interventions, residual stones or recurrent stones occur in 15-59\% of the cases (43). The presence of biliary stricture, impacted calculi, and unreached peripheral calculi are the main reasons for the failure of the procedure $(1,14)$. Many alternative methods have been tried and continue to be tried as a result of the deficiencies in treatment.

In HL surgery, interventions targeting the etiology should be firstly performed. These etiologies can be biliary strictures and anastomosis strictures secondary to past operations (14). The use of an operative cholangioscope in patients undergoing surgery to remove stones will facilitate the clearance of the bile 
ducts. The rate of residual $\mathrm{HL}$ after hepatectomy is 15.6\% (14). In patients with postoperative stones, stones can be removed in 60-90\% of the cases by postoperative choledochoscopy and endoscopic lithotomy $(14,17,18)$. After all treatment modalities, the bile ducts can be cleared from stones in $95 \%$ of cases. $(29,44)$. Eight cases in our series were treated with endoscopic methods, and their follow-up and treatment continue.

Partial resections, cholecystectomy, choledocholithotomy, choledochojejunostomy or T-tube placement have been preferred for many years when the location of the stones cannot be detected. Hepatectomy seems to be the most effective treatment since the stenotic area causing the stones is removed. Hepatectomy should be preferred in patients who cannot undergo stone extraction, who have abscess resistant to treatment, especially in patients with left lobe localization and in patients with atrophy and fibrosis $(6,10,14,45,46)$. Liver resection (two left lobe and two lateral sector) was performed in four of nine patients who underwent surgery in our series (Table 1). Two of the four patients who had previously undergone $\mathrm{HJ}$ underwent anastomosis revision, and a patient who developed stent ingrowth and another patient with anastomotic stenosis underwent aggressive resection and portoenterostomy. In another patient with $\mathrm{HJ}$ and bilateral $\mathrm{HL}$ due to biliary tract trauma, anastomotic revision, permanent access and stone extractions were performed, and the patient was observed without any complications for three years.

On the other hand, there are different approaches regarding liver resection. Feng et al. (10) have stated that Dong type 1 and type $2 \mathrm{~b}$ patients were good candidates for hepatectomy and they recommended $\mathrm{HJ}$ for patients with extrahepatic stones (type E). Kim et al. (4) have recommended lobectomy for patients suffering from $\mathrm{HL}$ for more than 10 years, due to the difficulties in the differential diagnosis and the risk of ICCA. However, there is not enough information about whether the operation has a protective effect on the risk of HL-ICCA development in those who undergo lobectomy. If there is no liver reserve problem in HL-ICCA cases, hepatectomy and regional lymph node dissection are the initial treatment option (Figure 4). In patients undergoing resection for $\mathrm{HL}-\mathrm{ICCA}$, 1 -year survival rate is $58 \%$ and in the $5^{\text {th }}$-year, this rate decreases to $10.6 \%$ (7). Surgical margin negativity $(>1 \mathrm{~cm})$ is one of the most important factors affecting survival positively $(47,48)$. In Zhu et al's (49) series of 38 patients with curative resection (R0), 1st and 5 th year survival rates have been confirmed as $71 \%$ and $50 \%$, respectively. As $40 \%$ of patients with HL-ICCA developed satellite lesions, there are also centers that prefer to have a larger hepatectomy $(47,48)$. Since survival is much higher in lymph node-negative patients than positive ones, regional lymph node dissection is recommended (50). The effect of adjuvant chemotherapy on survival is insufficient $(4,7,47)$.

Hepatectomies can be performed by laparotomy, laparoscopy and robotic methods. Laparoscopic hepatectomy is a tech- nique that can be used safely in both lobes, and it is the most preferred and recommended method especially for the cases localized in the left lobe or lateral sector (51). With the help of three-divisional visualization system (3DVS), the anatomy of the liver is revealed and it is possible to clearly reveal the location of the stenosis, stone, anomaly, and dilatation. In hepatectomies performed using 3DVS, it has been reported that more stones can be cleaned by using the rigid choledochoscope during the procedure $(43,52)$. It has been also reported that palliative resection procedures in the treatment of HL have a positive effect on survival $(53,54)$. The mortality rate of surgical treatment varies between 4-10\% (1).

According to the Dong classification, patients with Type IIC HL are candidates for liver transplantation. Transplantation is the only choice in patients with $\mathrm{HL}$ resulting in liver failure $(10,55)$. In patients who are resistant to treatment or in patients who cannot be operated, chemical hepatectomy may be tried by chemical bile duct embolization (CBDE) with experimentally proven chemical substances. However, there is a very limited number of clinical trials on this subject (56-58).

In conclusion, prevention of cholangitis attacks, prevention of strictures and development of ICCA should be prioritized in the treatment of $\mathrm{HL}$ patients. Endoscopy, radiology and surgical modalities should be applied with a multidisciplinary approach in the diagnosis and treatment of the disease. Treatment with endoscopic procedures and technological hand tools should be recommended first. Surgical resection should be the first choice in cases that develop atrophy, abscess, and ICCA. Efforts should be made to avoid HL due to its serious morbidity and serious adverse effects on life comfort. For this purpose, in addition to the prevention of biliary tract trauma, reconstruction and monitoring in experienced centers should be recommended. In patients with a high risk of stenosis, permanent access may be added to the procedure to facilitate recurrent endoscopic interventions. In order to prevent reflux to the biliary tract, it is more appropriate to perform hepaticojejunostomies in Roux-en-Y style.

Ethics Committee Approval: The approval for this study was obtained from Izmir Katip Çelebi University Non-Interventional Clinical Research Ethics Committee (Decision No: 260, Date: 30.05.2019).

Peer-review: Externally peer-reviewed.

Author Contributions: Concept - O.N.D., F.H.D.; Design - O.N.D., A.A.; Supervision - O.N.D., E.O.G., F.H.D.; Resource - N.A., A.A., O.Ö.; Materials - N.A., A.A., O.Ö., O.N.D., S..K.; Data Collection and/or Processing - O.N.D., Ş.K.; Analysis and Interpretation - O.N.D., S..K.; Literature Review - A.A., N.A.; Writing Manuscript - O.N.D., N.A., A.A.; Critical Reviews - O.N.D., F.H.D., A.A.

Conflict of Interest: The authors declare that they have no conflict of interest.

Financial Disclosure: The authors declared that this study has received no financial support. 


\section{REFERENCES}

1. Choi TK, Fok M, Lee MJR, Lui R, Wong J. Postoperative flexible choledochoscopy for residual primary intrahepatic stones. Ann Surg 1986; 203: 260-5. [CrossRef]

2. Mori T, Sugiyama M, Atomi Y. Gallstone disease: Management of intrahepatic stones. Best Pract Res Clin Gastroenterol 2006; 20: 1117-37. [CrossRef]

3. Lubezky N, Facciuto M, Harimoto N, Schwartz ME, Florman SS. Surgical treatment of intrahepatic cholangiocarcinoma in the USA. J Hepatobiliary Pancreat Sci 2015; 22: 124-30. [CrossRef]

4. Kim HJ, Kim JS, Joo MK, Lee BJ, Kim JH, Yeon JE, et al. Hepatolithiasis and intrahepatic cholangiocarcinoma: A review. World J Gastroenterol 2015; 21:13418-31. [CrossRef]

5. Ran X, Yin B, Ma B. Four major factors contributing to intrahepatic stones. Gastroenterol Res Practice 2017; 2017: 7213043. [CrossRef]

6. Tsui MS, Chan YK, Wong CT, Lo YF, Yeung YW, Lee YW, et al. Hepatolithiasis and the syndrome of recurrent pyogenic cholangitis: clinical, radiologic, and pathologic features. Sem Liver Dis 2011; 31: 33-48. [CrossRef]

7. Xiao J, Zhu J, Liu Z, Wan R, Li Y, Xiao W. Role of surgical treatment for hepatolithiasis-associated intrahepatic cholangiocarcinoma: A retrospective study in a single institution. J Cancer Res Ther 2017; 13: 756-60. [CrossRef]

8. Leung JW, YU AS. Hepatolithiasis and biliary parasites. Baillieres Clin Gastroenterol 1997; 11:681-706. [CrossRef]

9. Liu FB, YuXJ, Wang GB, Zhao YJ, Xie K, Huang F, et al. Preliminary study of a new pathological evolution-based clinical hepatolithiasis classification. World J Gastroenterol 2015; 21:2169-77. [CrossRef]

10. Feng X, Zheng S, Xia F, Ma K, Wang S, Bie P, et al. Classification and management of hepatolithiasis: a high-volume, single-center's experience. Intractable Rare Dis Res 2012; 1: 151-6. [CrossRef]

11. Cheon YK, Cho YD, Moon JH, Lee JS, Shim CS. Evaluation of long-term results and recurrent factors after operative and nonoperative treatment for hepatolithiasis. Surgery 2009; 146:843-53. [CrossRef]

12. Tsunoda T, Tsuchiya R, Harada N, Yoshino R, Noda T, Izawa K, et al. Long-term results of surgical treatment for intrahepatic stones. Jpn J Surg 1985; 15: 455-62. [CrossRef]

13. Suzuki Y, Mori T, Abe N, Sugiyama M, Atomi Y, et al. Predictive factors for cholangiocarcinoma associated with hepatolithiasis determined on the basis of Japanese multicenter study. Hepatol Res 2012; 42: 16670. [CrossRef]

14. Wen XD, Wang T, Huang Z, Zhang HJ, Zhang BY, Tang LJ, et al. Stepby-step strategy in the management of residual hepatolithiasis using post-operative cholangioscopy. Ther Adv Gastroenterol 2017; 10: 85364. [CrossRef]

15. Domagk D, Wessling J, Reimer P, Hertel L, Poremba C, Senninger N, et al. Endoscopic retrograde cholangiopancreatography, intraductal ultrasonography, and magnetic resonance cholangiopancreatography in bile duct strictures: a prospective comparison of imaging diagnostics with histopathological correlation. Am J Gastroenterol 2004; 99: 1684-9. [CrossRef]

16. Kondo S, Isayama H, Akahane M, Toda N, Sasahira N, Nakai Y, et al. Detection of common bile duct stones: comparison between endoscopic ultrasonography, magnetic resonance cholangiography, and helical-computed-tomographic cholangiography. Eur J Radiol 2005; 54: 271-5. [CrossRef]
17. Ma S, Hu S, Gao F, Liang R. Endoscopy lithotomy for intrahepatic gallstones: a meta-analysis. Surg Laparosc Endosc Percutan Tech 2015; 25: 269-74. [CrossRef]

18. Frossard JL, Morel PM. Detection and management of bile duct stones. Gastrointest Endosc 2010; 72: 808-16. [CrossRef]

19. Shoda J, Tanaka N, Osuga T. Hepatolithiasis - Epidemiology and pathogenesis update. Front Biosci 2003; 8: e398-409. [CrossRef]

20. Liang TB, Liu Y, Bai XL, Yu J, Chen W. Sphincter of Oddi laxity: An important factor in hepatolithiasis. World J Gastroenterol 2010; 16(8): 1014-8. [CrossRef]

21. Liu ZY, Zhou YM, Shi LH, Yin ZF. Risk factors of intrahepatic cholangiocarcinoma in patients with hepatolithiasis: a case-control study. Hepatobiliary Pancreat Dis Int 2011; 10:626-31. [CrossRef]

22. Chen TC, Nakanuma Y, Zen Y. Intraductal papillary neoplasia of the liver associated with hepatolithiasis. Hepatology 2001; 34: 651-8. [CrossRef]

23. Aishima S, Kubo Y, Tanaka Y, Oda Y. Histological features of precancerous and early cancerous lesions of biliary tract carcinoma. J Hepatobiliary Pancreat Sci 2014;21:448-52. [CrossRef]

24. Park HM, Hur YH, Cho CK, Koh YS, Kim HJ, Park EK. Incidence of underlying biliary neoplasm in patients after major hepatectomy for preoperative benign hepatolithiasis. Ann Hepatobiliary Pancreat Surg 2016: 20: 173-9. [CrossRef]

25. Zhou Q, Gong Y, Huang F, Lin Q, Zeng B, Li Z, et al. Expression levels and significance of nuclear factor-KB and epidermal growth factor receptor in hepatolithiasis associated with intrahepatic cholangiocarcinoma. Dig Surg 2013; 30: 309-16. [CrossRef]

26. Lee KT, Chang WT, Wang SN. Expression of DPC4/Smad4 gene in stone-containing intrahepatic bile duct. J Surg Oncol 2006; 94: 338-43. [CrossRef]

27. Bettschart V, Clayton RA, Parks RW, Garden OJ, Bellamy COC. Cholangiocarcinoma arising after biliary-enteric drainage procedures for benign disease. Gut 2002; 51: 128-9. [CrossRef]

28. Li C, Wen T. Surgical management of hepatolithiasis: A mini review. Intrac Rare Disease Res 2017; 6: 102-5. [CrossRef]

29. Lin CC, Lin PY, Ko JC, Chen LY, Chen ST, Kuo SJ. Hepatic resection for bilateral hepatolithiasis: a 20-year experience. ANZ J Surg 2013; 83: 978-84. [CrossRef]

30. Tazuma S, Nakanuma Y. Clinical features of hepatolithiasis: analyses of multicenter-based surveys in Japan. Lipids Health Dis 2015; 14:129. [CrossRef]

31. Tazuma S, Unno M, Igarashi Y, Inui K, Uchiyama K, Kai M, et al. Evidence based clinical guidelines for cholelithiasis 2016. J Gastroenterol 2017; 52: 276-300. [CrossRef]

32. Ros E, Navarro S, Bru C, Gilabert R, Bianchi L, Bruguera M. Ursodeoxycholic acid treatment of primary hepatolithiasis in Caroli's syndrome. Lancet 1993; 342: 404-6. [CrossRef]

33. DeVries E, Beuers U. Management of cholestatic disease in 2017. Liver Int 2017; 37: 123-9. [CrossRef]

34. Strichartz SD, Abedin MZ, Ippoliti AF, Derezin M, Roslynet JJ. Intrahepatic cholesterol stones: a rationale for dissolution therapy. Gastroenterology 1991; 100: 228-32. [CrossRef]

35. Guma C, Viola C, Apestegui M, Thomé U, Tani D, Kido N, et al. Hepatolithiasis and Caroli's disease in Argentina: results of a multicenter study [Article in Spanish with English abstract]. Acta Gastroenterol Latinoam 1999; 29: 9-15. [CrossRef] 
36. Suzuki Y, Mori T, Yokoyama T, Nakazato T, Abe N, Nakanuma Y, et al. Hepatolithiasis: analysis of Japanese nationwide surveys over a period of 40 years. J Hepatobiliary Pancreat Sci 2014; 21:617-22. [CrossRef]

37. Nakamura H, Hanyu F, Mazuno O, et al. The choledochoscopic examination. Gastrointestinal Endoscopy 1972; 14: 382-90. [CrossRef]

38. Lorio E, Patel P, Rosenkranz L, Patel S, Sayana H. Management of Hepatolithiasis: Review of the Literature. Curr Gastroenterol Rep 2020; 22(6): 30. Published 2020 May 7. [CrossRef]

39. Sheen-Chen SM, Cheng YF, Chen FC, Chou FF, Lee TY. Ductal dilatation and stenting for residual hepatolithiasis: a promising treatment strategy. Gut 1998; 42: 708-10. [CrossRef]

40. Kassem MI, Sorour MA, Ghazal AH, El-Haddad HM, El-Riwini MT, ElBahrawy HA. Management of intrahepatic stones: the role of subcutaneous hepaticojejunal access loop. A prospective cohort study. Int J Surg 2014; 12: 886-92. [CrossRef]

41. Ahmed S, Schlachter TR, Hong K. Percutaneous transhepatic cholangioscopy. Tech Vasc Interv Radiol 2015; 18: 201-9. [CrossRef]

42. Shin JS, Shim HJ, Kwak BK, Yoon HK. Biliary stone removal through the percutaneous transhepatic biliary drainage route focusing on the balloon sphincteroplasty flushing technique: a single center study with 916 patients. Jpn J Radiol 2017; 35: 440-7. [CrossRef]

43. Guan T, Fang C, Mo Z, Xiang N, Yang J, Zeng N. Long term outcomes of hepatectomy for bilateral hepatolithiasis with three-dimentional reconstruction: A propensity score matching analysis. J Laparoend Adv Tech 2016; 26: 680-8. [CrossRef]

44. Uenishi T, Hamba H, Takemura S, Oba K, Ogawa M, Yamamoto T. Outcomes of hepatic resection for hepatolithiasis. Am J Surg 2009; 198: 199-202. [CrossRef]

45. Dong J, Lau WY, Lu W, Zhang W, Wang J, Ji W. Caudate lobe-sparing subtotal hepatectomy for primary hepatolithiasis. Br J Surg 2012; 99: 1423-8. [CrossRef]

46. Sakpal SV, Babel N, Chamberlain RS. Surgical management of hepatolithiasis. HPB (Oxford) 2009; 11: 194-202. [CrossRef]

47. Bektas H, Yeyrek C, Kleine M, Vondran FWR, Timrott K, Schweitzer N, et al. Surgical treatment for intrahepatic cholangiocarcinoma in europe: A single center experience. J Hepatobiliary Pancreat Sci 2015; 22: 131-7. [CrossRef]

48. Spolverato G, Kim Y, Alexandrescu S, Popescu I, Marques HP, Aldrighettiet $L$, et al. Is hepatic resection for large or multifocal intrahepatic cholangiocarcinoma justified? Results from a multiinstitutional collaboration. Ann Surg Oncol 2015;22: 2218-25. [CrossRef]
49. Zhu QD, Zhou MT, Zhou QQ, Shi HQ, Zhang QY, Yu ZP. Diagnosis and surgical treatment of intrahepatic hepatolithiasis combined with cholangiocarcinoma. World J Surg 2014; 38: 2097-104. [CrossRef]

50. Clark CJ, WoodWentz CM, ReidLombardo KM, Kendrick ML, Huebner M, Que FG. Lymphadenectomy in the staging and treatment of intrahepatic cholangiocarcinoma: A populationbased study using the national cancer institute SEER database. HPB (Oxford) 2011; 13: 612-20. [CrossRef]

51. Li H, Zheng J, Cai JY. Laparoscopic VS open hepatectomy for hepatolithiasis: An updated systematic review and meta-analysis. World J Gastroenterol 2017; 23: 7791-806. [CrossRef]

52. Xiang N, Fang C. Application of hepatic segment resection combined with rigid choledochoscope in the treatment of complex hepatolithiasis guided by three-dimensional visualization technology. Zhonghua Wai Ke Za Zhi 2015; 53: 335-9. [CrossRef]

53. Li HY, Zhou SJ, Li M, Xiong D, Singh A, Guo QX, et al. Diagnosis and cure experience of hepatolithiasis-associated intrahepatic cholangiocarcinoma in 66 patients. Asian Pac J Cancer Prev 2012; 13: 725-9. [CrossRef]

54. Zhang XJ, Jiang Y, Wang X, Tian FZ, Lv LZ. Comparatively lower postoperative hepatolithiasis risk with hepaticocholedochostomy versus hepaticojejunostomy. Hepatobiliary Pancreat Dis Int 2010; 9: 38-43. [CrossRef]

55. Strong RW, Chew SP, Wall DR. Liver transplantation for hepatolithiasis. Asian J Surg 2002; 25: 180-3. [CrossRef]

56. Ma WJ, Zhou Y, Shrestha A, Mao H, Li FY, Cheng NS, et al. Applying chemical bile duct embolization to achieve chemical hepatectomy in hepatolithiasis: a further experimental study. J Surg Res 2014; 87: 113-21. [CrossRef]

57. Li FY, Jiang LS, de Jong MC, Cheng NS, Cheng JQ, Li N, et al. Clinical prospect of applying the chemical bile duct embolization to achieve a chemical hepatectomy in the treatment of highly selected hepatolithiasis. Surg Laparosc Endosc Percutan Tech 2009; 19: 183-7; discussion 7-9. [CrossRef]

58. Tsuyuguchi T, Miyakawa K, Sugiyama H, Sakai Y, Nishikawa T, Sakamoto $D$, et al. Ten-year long-term results after non-surgical management of hepatolithiasis, including cases with choledochoenterostomy. J Hepatobiliary Pancreat Sci 2014; 21: 795-800. [CrossRef] 


\section{ORIJINAL ÇALIŞMA-ÖZET}

\section{Hepatolityazis: klinik seri, değerlendirme ve güncel tedavi stratejisi}

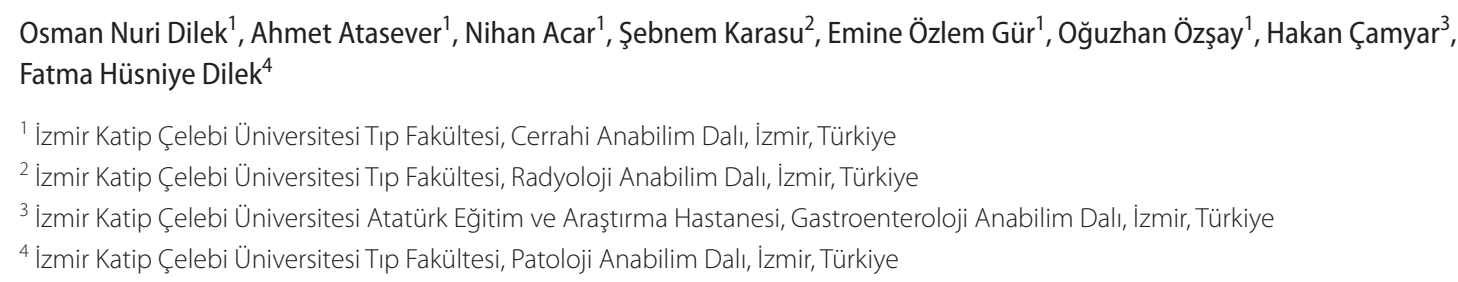

\section{ÖZET}

Giriş ve Amaç: Hepatolityazis (HL), lokal ve sistemik komplikasyonları, tedavi konusunda yetersizlikler ve nüks riskinin yüksekliği gibi nedenlerle problem olmaya devam etmektedir. Endoskopik girişimlerden, küçük bir segment rezeksiyonuna ve nihayetinde karaciğer transplantasyonuna kadar değişebilen cerrahi seçenekler mevcuttur. Bu makalemizde hepatolityazis tanısı almış hastalar ve uyguladığımız tedavi stratejileri literatür verileri ışı̆̆ında değerlendirilmiştir.

Gereç ve Yöntem: Çalışmada kliniğimizde 2014-2019 yılları arasında hepatolityazis tanısı almış hastalarımız ve uyguladığımız tedavi yöntemleri ,hasta dosyaları retrospektif olarak incelenerek değerlendirilmiştir. Hastaların demografik özellikleri, hastalık sebepleri, komplikasyonlar ve uygulanan tedavi seçenekleri irdelenmiştir.

Bulgular: Çalışmaya 17 hasta alınmıştır. Hastaların yaş ortalaması 64,3 (yaş aralı̆̆ı 32-89 yıl) tür. Yedi hastaya daha önceden kolesistektomi yapılmış olduğu saptandı. Kolesistektomi sırasında safra yolu travması gelişen üç hastadan ikisine hepatikojejunostomi, birine hepatikoduodenostomi yapıldığı ve darlık geliştiği saptandı. Bir hastada Whipple prosedürü sonrasında HJ yerinde darlık sonrasında HL gelişmişti. Kolesistektomi yapılmamış HL'li iki hastanın safra kesesinde taş yoktu. 9 hasta ameliyat edildi. İki hastaya sol hepatektomi, iki hastaya lateral sektör rezeksiyonu yapıldı. Anastomoz darlığı olan iki hastada $\mathrm{HJ}$ revizyonu, birinde stent ingrowth'u olan iki hastada anastomoz ve bifurkasyon rezeksiyonu ve neohepatikojejunostomi yapıldı. 8 hasta ise nonoperatif olarak medikal ve endoskopik yaklaşımlarla izleme alındı.

Sonuç: Hepatolityazis multimodal yaklaşımla tedavi edilmesi gereken ciddi bir durumdur. Stent uygulaması ve anastomoz darlığı hepatolityazis gelişimini kolaylaştırmakta ve görülme riskini artırmaktadır. Özellikle fonksiyonel hepatikojejunostomilerin yapılması bu komplikasyonun gelişimini azaltacaktır.

Anahtar Kelimeler: Anastomoz, etyoloji, hepatolityazis, safra yolu darlığı, tedavi

Doi: 10.47717/turkjsurg.2020.4551 